Bruff \& Tansel - Authoritarian Neoliberalism

\title{
Authoritarian Neoliberalism: Trajectories of Knowledge Production and Praxis
}

\author{
Ian Bruff (University of Manchester, UK) \& Cemal Burak Tansel \\ (University of Sheffield, UK)
}

\begin{abstract}
This introduction to the special issue takes as its point of departure three centres of gravity that have shaped the study of neoliberalism but have also established barriers to further progress in these debates. By promoting an intersectional materialist research agenda which challenges extant ideational, modernist and empiricist tendencies in scholarship on neoliberalism, the essay contextualizes the special issue articles by outlining and clarifying key aspects of our understanding of authoritarian neoliberalism. In particular, we reflect on themes related to conceptualization and periodization, which are of importance for both this special issue but also for broader questions of knowledge production and praxis. Through doing so, we argue that there are two distinct yet connected trajectories within the research agenda on authoritarian neoliberalism: one which focuses on the intertwinement of authoritarian statisms and neoliberal reforms; and another which traces various lineages of transformation of key societal sites in capitalism (e.g. states, households, workplaces, urban spaces). Recognition of this spectrum of authoritarian neoliberal practices is important as it helps us uncover how inequalities of power are produced and reproduced in capitalist societies, and pushes us to consider more fully how other worlds can be made possible. Nevertheless, it is affirmed that we must remain open to what an emancipatory society might look like, and what struggles would be most appropriate, in and across various socio-spatial contexts.
\end{abstract}

Keywords: authoritarian neoliberalism, neoliberalism, periodization, resistance, markets, coercion 
Bruff \& Tansel - Authoritarian Neoliberalism

Correspondence: Ian Bruff, Department of Politics, Arthur Lewis Building, University of Manchester, M13 9PL, UK, ianbruff@gmail.com

\section{Understanding Neoliberalism: Moving Away from Three Centres of Gravi- ty}

The conceptual value and political utility of neoliberalism continue to be significant faultlines in academic and public debates. On the one hand, many scholars increasingly question whether 'neoliberalism as a broad, catch-all term [can] adequately serve so many different phenomena and theoretical conceptualizations' (Venugopal, 2015, p. 165). On the other hand, the claim that public policies and state strategies that have been variously described as 'neoliberal' in the past three decades continue to dominate is accepted not only by scholars, but also by those who have often been portrayed as the architects of those policies (see Ostry et al., 2016). Coupled with the fact that 'neoliberalism' has not lost its popular and analytical resonance after the 2007-8 global economic crisis and throughout a state of 'permanent austerity' enacted especially but not only in Europe (Bailey, 2015), it is urgent that we consider these crucial questions:

- How do the practices, policies and ideas that are associated with 'neoliberalism' reproduce themselves in the face of crises and popular opposition?

- In what ways are such attempts at reproduction - in the current period, increasingly authoritarian and coercive - productive of new forms of crisis due to their contradictory nature?

- What lineages of transformation of key societal sites in capitalism (e.g. states, households, workplaces, urban spaces) can be traced to inform both our understanding of neoliberalism but also strategies for critiquing and resisting it?

- How do social struggles and various forms of resistance shape the manifestations of authoritarian neoliberalism, and how could they be utilized to generate visions of a more equitable future?

While debates on the conceptualization and utilization of neoliberalism continue to produce vibrant points of analytical contention, the term 'authoritarian neoliberalism' is fast becoming 
Bruff \& Tansel - Authoritarian Neoliberalism

an established part of critical social science scholarship, as shown by its deployment across numerous disciplinary and critical perspectives (for example, Bruff $(2014,2016)$, Bruff \& Wöhl (2016), Tansel (2017b, 2018), Wigger \& Buch-Hansen (2015), Yeşil (2016), Gonzales (2016), Smith (2018), and the contributions in Tansel, 2017a).

In our work, we locate the term at the intersection of a range of social relations and utilize it to highlight how contemporary capitalism is governed in a way which tends to reinforce and rely upon practices that seek to marginalize, discipline and control dissenting social groups and oppositional politics rather than strive for their explicit consent or co-optation. Such practices include the repeated invocations of 'the market' or 'economic necessity' to justify a wide range of restructurings across various societal sites (e.g. states, households, workplaces, urban spaces), the growing tendency to prioritize constitutional and legal mechanisms rather than democratic debate and participation, the centralization of state powers by the executive branch at the expense of popular participation and other nodes of governance, the mobilization of state apparatuses for the repression of oppositional social forces at a range of scales, and the heightened pressures and responsibilities shifted onto households by repeated bouts of crisis and the restructuring of the state's redistributive mechanisms. Nevertheless, for us, authoritarian neoliberalism is also understood as a crisis-ridden, contradictory set of practices which enhance the capacities and potentials for resistance as well as for domination. While the political and socio-economic developments that triggered the conceptualization of authoritarian neoliberalism tend to be understood from within a framework of progressive politics - such as the emphasis on the emergence of new sites of solidarity and autonomous movements seeking to prefigure a better world (see Huke et al., 2015) - we argue that resistances are multi-form and not always emancipatory, as signalled, for example, by the rise of new radical Right populism (see Konings, 2012).

Our aim in this collection of contributions to the rich debate on neoliberalism is to advance three main considerations, which together propose a departure from some of the limitations inherent to the well-established approaches in the literature. This is, by no means, a wholesale dismissal of the extant body of work on neoliberalism, but should be seen as an extension of a collective effort to move away from three centres of gravity that have shaped the study of neoliberalism but have also established barriers to further progress in these debates. With this objective in mind, and with a view to forging a stronger dialogue with cognate approaches to and critiques of neoliberalism in various branches of the social sciences, our contributions are framed thus: 
Bruff \& Tansel - Authoritarian Neoliberalism

I. We advocate an explicitly 'political' reading of neoliberalism, promoting an intersectional materialist research agenda in contrast to predominantly ideational approaches which have often been at the centre of debates about neoliberalism (for example, Mirowski \& Plehwe, 2009; Peck, 2010). The role of ideas and discourses is not to be discounted, and these works have been essential for advancing our understanding of neoliberalism beyond simplistic 'free market' narratives which also have a habit of essentializing states as inherently socially protective. However, these accounts, by virtue of their very focus, tend to underplay the connection between such ideas and discourses with capitalist development and statehood - plus with unequal social relations across society - and particularly their imbrication with coercive practices which seek to support and protect capital accumulation in the name of 'free markets' (Cahill, 2014). Moreover, these contributions set implicit faith in the potential of a new set of better ideas and discourses to displace and replace neoliberal practices. While laudable in a general sense, the works in this tradition do not say enough about the fact that ' $[\mathrm{m}]$ aterial circumstances are the net of constraints, the "conditions of existence" for practical thought and calculation about society' (Hall, 1996, p. 44), thus saying too little about how and why certain ideas come to dominate policy and preferences at particular points in time, as well as how and why they come to be contested (cf. Bieler \& Morton, 2008).

II. The special issue responds to the call made by Raewyn Connell and Nour Dados (2014, p. 134) to '[move] beyond the self-referentiality of Northern social science [and] towards a more democratic structure of theory on a world scale', which, for us, includes a more thorough examination of global South cases hitherto viewed as marginal to the study and especially the (re)constitution of neoliberalism. Neoliberalism in the global South has come to mean much more than what can be captured through the use of the traditional 'structural adjustment programme' analytical prism. Therefore, the special issue offers a wide range of empirical case studies that cover more ground than the Anglo-American centre of gravity that has long dominated the literature (see also Klein, 2007). In doing so, it challenges modernist and Eurocentric dichotomies about the forms taken by neoliberalism, which tend to contrast democratic capitalism in the global North with authoritarian development in the global South - i.e. as if 'capitalism' and 'development' can be neatly separated and mapped on to the world in an either/or fashion (see Tansel, 2017b). It is clear that countries such as the UK and the US, and relatedly Australia, Canada, Ireland and New Zealand, are important examples of neoliberalization, but this does not justify a strong focus on these spaces over others - a choice that ef- 
Bruff \& Tansel - Authoritarian Neoliberalism

fectively limits the potential for furthering our understanding of neoliberalism as well as skewing its conceptualization.

III. Our contributions move the debate decisively beyond the empiricist tendencies of some accounts of neoliberalism's resilience since 2007-8, which have largely superimposed commentary about the increasingly authoritarian forms taken by a resilient neoliberalism onto theoretical frameworks and approaches established prior to 2008 (for example, Schmidt \& Thatcher, 2013; Streeck, 2014; Ban, 2016). In various ways, the articles in the special issue take stock of the important contributions made by these accounts, but also aim to co-produce a research agenda more attuned to the significance of post-2008 shifts in socio-economic, legal and political landscapes. As we explore in detail below, highlighting this character of the crisis as a key conjuncture does not mean that the current trajectory of neoliberalism signifies a radical break from its pre-crisis orientation. Nor do we wish this consideration to be seen as a move that separates the association of neoliberalism from capitalism. Nevertheless, we contend that the crisis - and its accompanying aftershocks at various levels of governance and across a range of societies - did play an important role in heightening the extant antidemocratic tendencies of neoliberalism as well as generating new and mutated mechanisms that reproduce such tendencies. As such, our contributions complement some of the recent additions to the literature on neoliberalism (Wacquant, 2009; Soederberg, 2014; Springer, 2016) and simultaneously act as a call for the further shedding of some of the notions and assumptions which advanced our understandings of neoliberalism in the 1990s and 2000s, but ultimately require amendments in light of concrete political and socio-economic changes (e.g. the dominant focus on 'marketization' as a driver of neoliberalism).

Built on these premises, the special issue brings together contributions that further refine our conceptualization of the term 'authoritarian neoliberalism' and flesh out how the processes that we associate with it manifest in concrete contexts. In many ways, we utilize the space provided by this special issue to expand on the collective step taken towards formulating 'authoritarian neoliberalism' as a research agenda in States of Discipline: Authoritarian Neoliberalism and the Contested Reproduction of Capitalist Order (Tansel, 2017a), and to offer a targeted exercise in mapping practices, ideas and struggles that shape contemporary capitalism. Before covering the details of our contributions, we would like to take this opportunity to reflect on a number of issues related to the conceptualization and periodization of the concept, which we think are of importance not only for the current contributions at hand, but also for broader questions of knowledge production and praxis. 


\section{Embracing Messiness, or Why It Is Healthy to Work with Imperfect Con- cepts}

The $11^{\text {th }}$ European International Studies Association conference, organized in Barcelona in September $2017,{ }^{1}$ hosted a well-attended section on authoritarian neoliberalism. The call for this section attracted enough interest to enable 12 panels to take place across the conference, including a roundtable on States of Discipline (Tansel, 2017a). It was gratifying to witness such interest in the book and the concept, yet we were also struck by the tendency for certain types of well-meaning questions to be asked more than others - an experience which has been mirrored when we have delivered presentations elsewhere.

These questions often revolved around the desire for greater definitional clarity (for example, what we understand authoritarianism to be) and more precise conceptualizations of various elements of the research agenda (for instance, the exact relationship between consent and coercion). Some colleagues voiced the concern that authoritarian neoliberalism represents a top-down approach which neglects everyday life and the possibilities for grassroots change. Many of these questions prompted us to reflect on how we adopted, deployed and defined the concept, but also to think carefully about how we articulated and communicated our arguments in our work. As such, they produced helpful dialogues that displayed both the vibrancy of the debates around the concept and the existence of a number of issues that 'authoritarian neoliberalism', at least in its current incarnation, was not - and should not be - able to explain.

Nevertheless, given the persistence of certain requests for clarification, we realized that some of these exchanges spoke to the formalized nature of knowledge production that is encouraged and, indeed sanctioned, in many parts of the social sciences - for instance, the privileging of modes of reasoning which embody and promote an incessant drive for categorizability. In principle, this categorization drive opens up the possibilities for dialogue between protagonists in various literatures, for having an analytical common ground helps provide a basis for the debates that unfold. But what happens when the very basis for the debates, the categories themselves, start mutating in front of our eyes and we are forced to reflect on the way we understand the world? Here we concur wholeheartedly with Joseph Buttigieg (1990, p. 81), when he argues that 'if the relationship among the fragments [of our knowledge] were 
Bruff \& Tansel - Authoritarian Neoliberalism

permanently fixed, then the concepts and theories would crystallize into dogmas'. We can, for example, trace the negative analytical consequences of utilizing neoliberalism in an inflexible way in how dominant Anglocentric conceptions have struggled to explain the complexities of cases emanating from the global South. Similarly, the governance of neoliberalism in the aftermath of the 2007-8 crisis has accentuated the need to rethink the relationship between the capitalist state and the role of the law in regulating and reproducing dominant policy paradigms, with law all too often being understood in a descriptive and analytically/politically neutral manner.

It is important to highlight that we acknowledge the value of crafting arguments which are well-informed, coherent and persuasive, but on the other hand, we agree with Jennifer Mason (2011, p. 80) on the importance of adopting a less orthodox approach to concept formation, which should not be seen as antithetical to analytical 'rigour':

if we want to create flashes of insight we need researchers to be active and imaginative agents...when they ask themselves how they can get hold of some pivotal, incisive, crucial or vital things... They need to make inventive and even ingenious decisions about which might be particularly compelling lines of enquiry and this cannot be done with deductive reasoning and following predefined methodological procedures alone.

Therefore, we would like to reiterate our contention that authoritarian neoliberalism does capture important global trends that warrant our attention, but it is not a template conceptualization that can be uncritically applied across the world or across time. Hence the discussion in our work of practices, repertoires and spectrums rather than an attempt to formulate strict typologies and models. Moreover, observe the evolution in Bruff's work to acknowledge the relative absence of feminist scholarship in his earlier contributions (compare Bruff, 2014 with Bruff \& Wöhl, 2016), and the explicit statement in Tansel's introduction to States of Discipline that the volume should not be seen as the culmination of a completed research project, with 'the particular gendered, racialized and localized effects of authoritarian neoliberalism, as well as their relationship with the contemporary forms of indebtedness, financialization, migration and globalized conflict' requiring greater future scrutiny (Tansel, 2017b, p. 18).

This leads us to a more specific point about the intellectual inspirations for our initial forays into this area of work. In both cases (Bruff, 2014; Tansel, 2017a), parity of esteem was accorded to Antonio Gramsci, Stuart Hall, and Nicos Poulantzas. Tellingly, while Gramsci and especially Poulantzas are referenced in questions asked of us at conferences, Hall is fre- 
Bruff \& Tansel - Authoritarian Neoliberalism

quently conspicuous by his absence. What might this be emblematic of? For us, it is the aforementioned, formalized modes of reasoning: as a scholar associated with Cultural Studies and sometimes Sociology, Hall - we infer - must be seen as someone who can only help us gain insight into the cultural aspects of authoritarian neoliberalism, such as the role of the media in promoting debt-laden consumerism. Such a set of assumptions is highly problematic for embodying dichotomies such as culture/politics, state/society and formal/informal, refracting the notion of authoritarian neoliberalism through narrow prisms. More damagingly, it neglects the fact that, precisely because he viewed the world he studied as constituted by a plurality of sites and practices, Hall can be understood as a politicized and politicizing scholar in all respects. ${ }^{2}$ Politics does not just reside in the state, policy-making, election campaigns, and so on; it is immanent to all social relationships and sites. Not for nothing was he the person to coin the term 'Thatcherism' prior to Thatcher becoming Prime Minister, and to identify its contradictions earlier than almost anybody else.

Crucially for our purposes, on neoliberalism Hall argued that the "term "neoliberal" is not a satisfactory one...However, I think there are enough common features to warrant giving it a provisional conceptual identity, provided this is understood as a first approximation' (Hall, 2011, p. 10; original emphasis). This is not simply because Hall is imploring us to understand neoliberalism in its multiple instantiations, though that is part of the story. It also means that:

No project achieves 'hegemony' as a completed project. It is a process, not a state of being. No victories are permanent or final. Hegemony has constantly to be 'worked on', maintained, renewed, revised. Excluded social forces, whose consent has not been won, whose interests have not been taken into account, for the basis of counter-movements, resistance, alternative strategies and visions...and the struggle over a hegemonic system starts anew. They constitute what Raymond Williams called 'the emergent' - and are the reason why history is never closed but maintains an open horizon towards the future (Hall, 2011, p. 26).

In other words, and in contrast to approaches which project resistance to neoliberalism as something that is thrust upon the capitalist state by forces from outside that are analytically and methodologically separate from politics and governance (e.g. Gill, 2000; Harvey, 2005; Foucault, 2008), we instead see social struggles as traversing all parts of society, including the state. More to the point, it is possible to envision and place at the heart of our research the potentials for things to be different in the future if we reject over-formalized forms of 
Bruff \& Tansel - Authoritarian Neoliberalism

knowledge of production and instead embrace the inevitable messiness inherent to the study of socio-economic, legal, and political landscapes that are shifting in front of us, in our own lifetimes (cf. Montesinos Coleman, 2015). The research agenda of authoritarian neoliberalism, for all of its apparent pessimism and seeming focus on domination, reveals that the way we live today is not inevitable because it is actively constructed by competing social forces, and that our modes of living could be different in the future for the same reason.

As noted earlier in the article, resistance in the current period is multi-form and points to a range of possible future 'post-neoliberal' developments, from regressive to transformative. Additionally, if we are committed to acknowledging and understanding practices, repertoires and spectrums rather than attempting to formulate strict typologies and models, then it is imperative that we remain open to what an emancipatory society might look like, and what struggles would be most appropriate, in and across various socio-spatial contexts. Nevertheless, we close this section by affirming a core motivation for pursuing the research agenda on authoritarian neoliberalism: by becoming more attuned to how inequalities of power are produced and reproduced in capitalist societies, we are able to consider more fully how other worlds can be made possible. The world could be more equitable if, in the process of understanding, critiquing and challenging authoritarian neoliberalism, we can find a way to reconstruct states and societies according to values such as equality, justice, dignity, and solidarity.

\section{Two Strategies for Unpacking the Lineages of Authoritarian Neoliberalism}

This living and evolving character of the concept also raises some important questions about understanding the novelty and historicity of the practices that we associate with authoritarian neoliberalism. Some critical treatments of the concept we have come across in conference discussions focus on this issue, highlighting the dangers of disassociating non-democratic practices from a broader history of neoliberalism and capitalism - a concern often accompanied by the call to recognize that neoliberalism and capitalism have always been 'authoritarian'. This is an important point, which reminds us to pay attention to, for example, the tensions created by the political organization of capitalism which continually build barriers against substantial democratization, as well as to the fact that many instances of neoliberal reforms across the world materialized through the deployment of highly coercive state strategies. Yet, we are not entirely convinced how this issue applies to the way in which we have attempted to 
Bruff \& Tansel - Authoritarian Neoliberalism

formulate the concept, as our own sketches have been shaped by two complementary sensitivities that stress both the 'authoritarian' continuities and the qualitative transformations in the lineages of actually existing neoliberalisms.

With regards to the novelty of authoritarian neoliberalism - and in particular, of the practices that have become more visible in the aftermath of the global economic crisis - we have maintained that these developments should not be seen as amounting to a wholesale break from neoliberal practices prior to 2007 (Bruff, 2014, p. 116). On the contrary, we have repeatedly contextualized such practices within the longer trajectory of neoliberalism, and insisted that the focus on authoritarian neoliberalism:

should not be read to the effect that the deployment of coercive state apparatuses for the protection of the circuits of capital accumulation is a new phenomenon, nor should it lead to the assumption that the pre-crisis trajectories of neoliberalization have been exclusively consensual' (Tansel, 2017b, pp. 2-3; original emphases).

At the same time, our collective work with colleagues has demonstrated that neoliberal projects have increasingly relied on a constellation of legal, administrative and coercive state apparatuses to both legitimize and shield themselves from political and social contestation. Such measures and practices could be interpreted as merely updated incarnations of capitalism's (or neoliberalism's) inherent authoritarian tendencies, but we think it is crucial to conduct a more surgical analysis and examine carefully how these practices differ from established logics of capitalist statecraft. Put bluntly, rejecting the authoritarian character of contemporary capitalism on the grounds that capitalism itself possesses non-democratic tendencies is a counterproductive strategy. While it is important to take into account systemic imperatives in explaining why capitalism produces authoritarian governance, we cannot reduce all instances and forms of authoritarian practices to a general capitalist law of motion. Doing so obscures a vast spectrum of governance techniques and potential ways to resist and overcome them, and risks producing, in the process of invoking the need to produce a more accurate picture of periodization, an ahistorical account of temporally seamless authoritarian capitalist statecraft.

Furthermore, authoritarian neoliberalism captures two distinct research trajectories: one focusing on the intertwinement of authoritarian statisms and neoliberal reforms; and another which traces various lineages of transformation of key societal sites in capitalism (e.g. states, households, workplaces, urban spaces), via spatially and temporally uneven yet cumulative neoliberalization processes that are observable across different cases. These are not mutually 
Bruff \& Tansel - Authoritarian Neoliberalism

exclusive orientations, but they ultimately prioritize a different set of research questions and would suggest different political strategies when considering questions of resistance. In the first trajectory, the concept could be deployed to explore how neoliberalization in authoritarian states produces a symbiotic configuration whereby the reforms are enacted and protected through existing mechanisms of authoritarian statecraft. The historical trend of neoliberalization through authoritarianism is an important part of the story of Latin American and Middle Eastern cases (Bedirhanoğlu \& Yalman, 2010), and more recent research has demonstrated the significance of this co-constitutive relationship in the cases of China and Cambodia (Lim, 2017; Springer 2017). In the second trajectory, the focus is more decisively on sets of neoliberal practices employed not only in authoritarian states but also in formally democratic regimes to further protect spaces and circuits of capitalist accumulation, and how such practices are dependent for their effectiveness on their ongoing, varying and frequently conflictual entanglement with key societal sites such as households, workplaces, and urban spaces. Here, the particular administrative and legal efforts to limit the social and political space for contesting those ideas/policies, as well as to facilitate a broader realignment of public power away from democratic politics, takes priority.

Contributions to this special issue are situated within these two trajectories, and by doing so, reveal both the continuities in some of the neoliberalization processes under scrutiny, and the qualitative changes experienced in the others - particularly (but not only) in relation to executive centralization and legislative activism, and conflictual entanglements between these evolutions and other key societal sites.

\section{Outlining the Special Issue}

The special issue contains eight articles in addition to this introductory essay, and they can be considered in pairs. The papers by Ian Bruff \& Kathryn Starnes and by Mareike Beck \& Julian Germann take issue with the position of 'the market' in neoliberal thought and practice. Bruff \& Starnes utilize a literary-theoretical approach to argue that neoliberalism, even in 'pure' theory texts by key intellectuals such as Friedrich Hayek and Milton Friedman, has never been about free markets. Bruff \& Starnes emphasize the crucial role of states and households instead; in contrast, Beck \& Germann's article points to the importance of corporate hierarchies and management techniques in the emergence of German neoliberalism. This 
Bruff \& Tansel - Authoritarian Neoliberalism

enables them to claim that Germany was neither a latecomer to neoliberalism; nor was it necessarily distinct from 'Anglo' countries because of the role of ordoliberal ideas (as suggested by many commentaries on neoliberalism with German characteristics).

Graham Harrison and Nadine Kreitmeyr provide regional overviews of African and MENA (Middle East and North Africa) countries. In doing so, they highlight how seemingly more inclusive governing strategies can give the impression of a move away from neoliberalism to more enlightened politico-economic projects. However, Harrison notes that more 'developmental' strategies, while with greater chances of sustained capital accumulation than their neoliberal equivalents, do not necessarily lead to the more democratic or equal society that critics of neoliberalism often assume. Conversely, Kreitmeyr argues that the growth of social entrepreneurship networks may suggest a pluralization and partial liberalization of these societies, but are presently serving to forge paths of authoritarian renewal via neoliberal co-optation. As such, both papers remind us of the importance of conceptual reflection when considering the term 'authoritarianism' as well as that of 'neoliberalism'.

The papers by Alke Jenss and Cemal Burak Tansel continue the challenge to modernist dichotomies, but zoom in from the regional to the urban scale. This is important, for struggles around security and housing have been central to (in Jenss' article) 'austerity urbanism' and to what Tansel understands as the commodification of public space and housing. More specifically, Jenss extends previous work on authoritarian neoliberalism by considering the coloniality of power in local forms of statehood in southern Mexico, and the consequences this has for studying localized expressions of formal and informal social relations. Tansel's article contests another common binary, between national and local levels of governance in the production of neoliberal reforms. He shows how the selective mobilization of executive powers, particularly through judicial and administrative restructuring, have been utilized in Turkey to increase the scope of commodification of urban land and in housing, as well as to strengthen the presence of state coercion across multiple sites.

The final two papers consider a well-known theme in debates on authoritarian neoliberalism, the Eurozone crises and responses to them at supranational, national and local scales. Nevertheless, Adriano Cozzolino and Angela Wigger paint a different picture of their cases compared to the norm. Cozzolino continues Tansel's discussion of executive centralization, showing that the narrowing down of political space to contest policy, via constitutionalization, emergency laws and administrative restructuring, has been ongoing in Italy since the late 1970s. Therefore, while these processes have intensified in the last decade, Cozzolino's analysis dovetails with our points about periodization in this essay. Wigger's critique of the Euro- 
Bruff \& Tansel - Authoritarian Neoliberalism

pean Union's so-called new industrial policy shows that real change will not come from EU institutions as currently configured, but instead from entirely different practices which have as their premise democratically-managed social relations of (re)production; moreover, such understandings are currently proliferating in European solidarity economy initiatives.

Inevitably, collections such as this special issue cannot cover all aspects of the topic and related themes. Therefore, we will use the conclusion to discuss the objectives of the special issue and where future research on authoritarian neoliberalism could take us.

\section{Conclusion and Pointers for Future Research}

The special issue aims to fulfil the following objectives:

Advancing new conceptual and methodological tools to bolster the study of neoliberalism. In addition to its focus on conceptualizing authoritarian neoliberalism, this collection features empirical case studies built on approaches and methods that are relatively under-utilized in the literature (e.g. literary theory, archival research, legal analysis). The articles further promote interdisciplinary dialogue by echoing some of the cognate debates in anthropology and Area Studies (see Guarneros-Meza \& Geddes, 2010; Eriksen et al., 2015).

Rectifying a number of significant empirical and geographical lacunae in accounts of neoliberalism. The special issue articles on Middle Eastern, African and Latin American cases help to decentre the dominant narrative on neoliberalism. We present these cases not as empirical 'additions' to an otherwise unproblematized theoretical edifice, but the building blocks of our new research agenda that takes local histories, socio-economic conditions and political struggles seriously. We further believe that these case studies will be of utmost importance to the broader International Political Economy and economic sociology literatures, given the extent to which the former in particular has been complicit in overlooking the Middle East and Africa as sites of analysis (be it through neglect of the cases or the failure to avoid the capitalism/development binary discussed earlier).

Informing political struggles and envisioning alternative futures. Reform of or alternatives to capitalism have achieved greater prominence in recent years, reaching beyond academic liter- 
Bruff \& Tansel - Authoritarian Neoliberalism

atures to inform popular debates (see Piketty, 2014; Mason, 2015). They have also led to a revival in autonomist and related writings on self-organization and new forms of resistance (see Federici, 2012; Holloway, 2016). However, many still understand the struggle against neoliberalism to be resistance against marketization. This special issue challenges assumptions which associate too strongly neoliberalism with economics or free markets per se, as part of a broader attempt to rethink progressive politics and strategies. As a result, the special issue invites us to consider the significance of a broader range of resistances. This does not downplay more formal forms of politics, but it does mean that we ought not to restrict ourselves to political parties, trade unions, and established civil society organizations. A broader perspective would also address, for instance, labour activisms which challenge legal restrictions and neglectful trade unions (such as in China), place-based struggles that embody radically different understandings of development (such as among indigenous peoples in Latin America), spatially diffused but socially connected movements against racialized coercion and militarized forms of policing (such as Black Lives Matter), community-centred responses and resistances to intensified crises of social reproduction (such as the PAH's actions in Spain to prevent evictions and fight for the right to housing), and finally the wide range of solidarity economy initiatives that exist across the world which attempt to prefigure the world that they wish to see. To be clear, this does not obviate the need to engage with more formalized forms of politics, but we should adjust our worldview in order to understand and discuss the interconnections between various resistances and struggles and how they inform and shape each other.

Hence, by making important conceptual and methodological advances and through addressing a number of empirical and geographical lacunae, the possibilities for scholarship on authoritarian neoliberalism to inform political and social struggles and to envision alternative futures are significantly increased. In particular, every article in the special issue undermines established 'facts' about neoliberalism in thought and in practice, pointing in the process towards new avenues for research and for political and social praxis. Moreover, every article cautions readers about the inevitably loaded nature of terms such as 'markets', 'democracy', 'authoritarianism', 'households', 'competition', and 'social', thus hopefully helping to foster a dialogue which does not take such concepts for granted when considering strategies of critique and resistance.

This leads us to future research on authoritarian neoliberalism. This list is not exhaustive, but all would help enrich further the work already being done: genealogies of authoritarian neoliberalism in earlier contributions from a range of neoliberal intellectuals; the intertwining 
Bruff \& Tansel - Authoritarian Neoliberalism

of more commercial and more securitized forms of power, especially in terms of violence and policing; understandings of and struggles over the term 'public', be it in terms of public services, public spaces, public goods, and so on; enhanced connections and dialogues between a greater range of critical-theoretical approaches (for example, historical materialist, feminist, postcolonial, anarchist); the notion of the 'non-market', so central to neoliberalism yet also the potential basis for an alternative society in the future (e.g. the solidarity economy); and anthropologies of resistance in their particular socio-spatial contexts. Much work lies ahead of us.

\section{Acknowledgements}

We would like to thank the participants of the section 'Authoritarian Neoliberalism: Dominations, Crises, Resistances', organized at the $11^{\text {th }}$ European International Studies Association conference in Barcelona (13-16 September 2017), and in particular to Victoria Basham, Katharina Bodirsky, Sébastien Rioux and Ilona Steiler for their feedback and contributions. Additionally, the Critical Political Economy Research Network has been valuable for Ian Bruff in particular, across many years. Many of the ideas expressed in this piece have been shaped by our conversations with David Bailey, Andreas Bieler, Mònica Clua-Losada, Brecht De Smet, Juanita Elias, Laura Horn, Johannes Jäger, Lara Montesinos Coleman, Adam David Morton, Reecia Orzeck, V. Spike Peterson, Adrienne Roberts, Roberto Roccu, Alfredo SaadFilho, Susanne Soederberg, Simon Springer, Liam Stanley, Kathryn Starnes, Angela Wigger, Stefanie Wöhl, and Yuliya Yurchenko. We extend our gratitude to them for their generous support. Finally, we would like to thank the editors of Globalizations, especially Barry Gills, for supporting the proposal for this special issue.

\section{Disclosure Statement}

No potential conflict of interest was reported by the authors. 
Bruff \& Tansel - Authoritarian Neoliberalism

\section{References}

Bailey, D. (2015). Resistance is futile? The impact of disruptive protest in the silver age of permanent austerity'. Socio-economic Review, 13(1), 5-32.

Ban, C. (2016). Ruling Ideas: How Global Neoliberalism Goes Local. Oxford: Oxford University Press.

Bedirhanoğlu, P. \& Yalman, G. L. (2010). State, class and the discourse: Reflections on the neoliberal transformation in Turkey. In A. Saad-Filho \& G. L. Yalman (Eds.), Economic transitions to neoliberalism in middle-income countries (pp. 107-127). Abingdon: Routledge.

Bieler, A., \& Morton, A. D. (2008). The deficits of discourse in IPE: Turning base metal into gold? International Studies Quarterly, 52(1), 103-128.

Bruff, I. (2014). The rise of authoritarian neoliberalism. Rethinking Marxism, 26(1), 113-129.

Bruff, I. (2016). Neoliberalism and authoritarianism. In S. Springer, K. Birch, \& J. MacLeavy (Eds.), The handbook of neoliberalism (pp. 107-117). New York: Routledge.

Bruff, I., \& Wöhl, S. (2016). Constitutionalizing austerity, disciplining the household: Masculine norms of competitiveness and the crisis of social reproduction in the Eurozone. In A. Hozić \& J. True (Eds.), Scandalous economics: Gender and the politics of financial crises (pp. 92-108). Oxford: Oxford University Press.

Buttigieg, J. A. (1990). Gramsci's method. Boundary 2, 17(2), pp. 60-81.

Cahill, D. (2014). The end of laissez-faire? On the durability of embedded liberalism. Cheltenham: Edward Elgar.

Connell, R. \& Dados, N. (2014). Where in the world does neoliberalism come from? The market agenda in Southern perspective. Theory and Society, 43(2), 117-138.

Eriksen, T. H., Laidlaw, J., Mair, J., Martin, K. \& Venkatesan, S. (2015) Debate: The concept of neoliberalism has become an obstacle to the anthropological understanding of the twenty-first century. Journal of the Royal Anthropological Institute, 21(4), 911-923.

Federici, S. (2012). Revolution at point zero: Housework, reproduction, and feminist struggle. Oalkland: PM Press.

Foucault, M. (2008). The birth of biopolitics: Lectures at the Collège de France, 1978-1979 (translated by G. Burchell). New York: Palgrave Macmillan. 
Bruff \& Tansel - Authoritarian Neoliberalism

Gill, S. (2000). Towards a postmodern prince? The battle in Seattle as a moment in the new politics of globalisation. Millennium, 29(1), 131-140.

Gonzales, A. (2016). Neoliberalism, the Homeland Security state, and the authoritarian turn. Latino Studies, 14(1), 80-98.

Guarneros-Meza, V. \& Geddes, M. (2010). Local governance and participation under neoliberalism: Comparative perspectives. International Journal of Urban and Regional Research, 34(1), 115-129.

Hall, S. (1996). The problem of ideology: Marxism without guarantees. In D. Morley \& K.-H. Chen (Eds.), Stuart Hall: Critical dialogues in cultural studies (pp. 25-46). London: Routledge.

Hall, S. (2011). The neoliberal revolution. Soundings, 48, 9-27.

Harvey, D. (2005). A brief history of neoliberalism. Oxford: Oxford University Press.

Holloway, J. (2016). In, against, and beyond capitalism: The San Francisco lectures. Oakland: PM Press.

Huke, N., Clua-Losada, M. \& Bailey, D. J. (2015) Disrupting the European crisis: A critical political economy of contestation, subversion and escape. New Political Economy, 20(5), $725-751$

Klein, N. (2007) The shock doctrine: The rise of disaster capitalism. London: Allen Lane.

Konings, M. (2012). Imagined double movements: Progressive thought and the specter of neoliberal populism. Globalizations, 9(4), 609-622.

Lim, K. F. (2017). Variegated neoliberalization as a function and outcome of neoauthoritarianism in China. In C. B. Tansel (Ed.), States of discipline: Authoritarian neoliberalism and the contested reproduction of capitalist order (pp. 255-273). London: Rowman \& Littlefield International.

Mason, J. (2011). Facet methodology: The case for an inventive research orientation. Methodological Innovations Online, 6(3), 75-92.

Mirowski, P. \& Plehwe, D. (Eds.) (2009). The road from Mont Pelerin: The making of the neoliberal thought collective. Cambridge: Harvard University Press.

Montesinos Coleman, L. (2015). Ethnography, commitment, and critique: Departing from activist scholarship. International Political Sociology, 9(3), 263-280.

Ostry J. D., Loungani, P. \& Furceri, D. (2016). Neoliberalism: Oversold? Finance \& Devel$\begin{array}{llll}\text { opment, } & 53(2), & \text { 38-41. } & \text { Retrieved }\end{array}$ http://www.imf.org/external/pubs/ft/fandd/2016/06/pdf/ostry.pdf

Peck, J. (2010). Constructions of neoliberal reason. Oxford: Oxford University Press. 
Bruff \& Tansel - Authoritarian Neoliberalism

Schmidt, V. A. \& Thatcher, M. (Eds.) (2013). Resilient liberalism in Europe's political economy. Cambridge: Cambridge University Press.

Smith, C. (2018). Race and the logic of radicalisation under neoliberalism. Journal of Sociology, 54(1), 92-107.

Soederberg, S. (2014). Debtfare states and the poverty industry: Money, discipline and the surplus population. Abingdon: Routledge.

Springer, S. (2016). The discourse of neoliberalism: An anatomy of a powerful idea. London: Rowman \& Littlefield International.

Springer, S. (2017). Klepto-neoliberalism: Authoritarianism and patronage in Cambodia. In C. B. Tansel (Ed.), States of discipline: Authoritarian neoliberalism and the contested reproduction of capitalist order (pp. 235-254). London: Rowman \& Littlefield International.

Streeck, W. (2014). How will capitalism end? New Left Review, 2(87), 35-64.

Tansel, C. B. (Ed.) (2017a). States of discipline: Authoritarian neoliberalism and the contested reproduction of capitalist order. London: Rowman \& Littlefield International.

Tansel, C. B. (2017b). Authoritarian neoliberalism: Towards a new research agenda. In C. B. Tansel (Ed.), States of discipline: Authoritarian neoliberalism and the contested reproduction of capitalist order (pp. 1-28). London: Rowman \& Littlefield International.

Tansel, C. B. (2018). Authoritarian neoliberalism and democratic backsliding in Turkey: Beyond the narratives of progress. South European Society and Politics, 23(2), 197-217.

Venugopal, R. (2015). Neoliberalism as concept. Economy and Society, 44(2), 165-187.

Yeşil, B. (2016). Media in new Turkey: Origins of an authoritarian neoliberal state. Chicago: University of Illinois Press.

Wacquant, L. (2009). Punishing the poor: The neoliberal government of social insecurity. Durham: Duke University Press.

Wigger, A. \& Buch-Hansen, H. (2015). EU competition regulation: A case of authoritarian neoliberalism?' In P. F. Kjaer \& E. Hartmann (Eds.), The evolution of intermediary institutions in Europe: From corporatism to governance (pp. 81-98). London: Palgrave Macmillan.

\section{Notes on contributors}


Bruff \& Tansel - Authoritarian Neoliberalism

Ian Bruff is Lecturer in European Politics at the University of Manchester, UK. He has published widely on capitalist diversity, European capitalisms, neoliberalism, and social theory. $\mathrm{He}$ is currently researching the foundations of neoliberal thought, and is the Managing Editor of the Transforming Capitalism book series published by Rowman \& Littlefield International.

Cemal Burak Tansel is Lecturer in International Politics at the University of Sheffield, UK. His research focuses on the historical sociology of state formation and capitalist development in the Middle East and the political economy of development. He is the editor of States of discipline: Authoritarian neoliberalism and the contested reproduction of capitalist order (Rowman \& Littlefield International, 2017) plus the author of numerous journal articles and book chapters.

\footnotetext{
Notes

${ }^{1}$ Around the time of the conference, the city itself became a key site for the manifestation of the crisisridden and highly contested assertion of national state power, and embodied the fundamental incoherence of the Spanish state in its localized expressions. Moreover, for some involved in the independence struggle, at stake was not just local sovereignty but transformed and democratized forms of selfgovernance as well.

${ }^{2}$ Many thanks to Kathryn Starnes for this point.
} 